University of Nebraska - Lincoln

DigitalCommons@University of Nebraska - Lincoln

USDA Forest Service / UNL Faculty Publications U.S. Department of Agriculture: Forest Service -National Agroforestry Center

1991

Temporal analysis and spatial mapping of Lymantria dispar nuclear polyhedrosis virus transcripts and in vitro translation polypeptides

James M. Slavicek

USDA Forest Service

Follow this and additional works at: https://digitalcommons.unl.edu/usdafsfacpub

Part of the Forest Sciences Commons

Slavicek, James M., "Temporal analysis and spatial mapping of Lymantria dispar nuclear polyhedrosis virus transcripts and in vitro translation polypeptides" (1991). USDA Forest Service / UNL Faculty Publications. 137.

https://digitalcommons.unl.edu/usdafsfacpub/137

This Article is brought to you for free and open access by the U.S. Department of Agriculture: Forest Service -National Agroforestry Center at DigitalCommons@University of Nebraska - Lincoln. It has been accepted for inclusion in USDA Forest Service / UNL Faculty Publications by an authorized administrator of DigitalCommons@University of Nebraska - Lincoln. 


\title{
Temporal analysis and spatial mapping of Lymantria dispar nuclear polyhedrosis virus transcripts and in vitro translation polypeptides
}

\author{
James M. Slavicek \\ USDA Forest Service, Northeastern Forest Experiment Station, 359 Main Road, Delaware, \\ Ohio 43015, U.S.A.
}

(Received 4 October 1990; revision received 7 March 1991; accepted 12 April 1991)

\section{Summary}

Genomic expression of the Lymantria dispar multinucleocapsid nuclear polyhedrosis virus (LdMNPV) was studied. Viral specific transcripts expressed in cell culture at various times from 2 through $72 \mathrm{~h}$ postinfection were identified and their genomic origins mapped through Northern analysis. Sixty-five distinct transcripts were identified in this analysis. Most viral transcripts were expressed late in infection, and originated from throughout the viral genome. Viral polypeptides expressed in infected $652 Y$ cells were labeled with ${ }^{35}$ S $]$ methionine and identified by autoradiography after separation by SDS polyacrylamide gel electrophoresis. Viral protein synthesis was found to occur in a sequential manner. Four proteins were identified in the early phase of viral replication (4-12 h p.i.), 24 proteins in the intermediate phase (12-24 h p.i.), and 5 proteins during the late phase ( $>24 \mathrm{~h}$ p.i.). Cytoplasmic RNAs were isolated from LdMNPV infected cells at 16,24 , and $48 \mathrm{~h}$ p.i., and used for hybrid selections with overlapping DNA fragments that covered the entire LdMNPV genome. The selected RNAs were translated in vitro, and 61 distinct viral polypeptides were identified and their genomic origins mapped. Temporal and spatial transcription and translation maps of the LdMNPV genome were generated with these data, and the expression pattern of the LdMNPV genome was compared to that of the Autographa californica nuclear polyhedrosis virus.

Baculovirus; Lymantria dispar nuclear polyhedrosis virus; Gene expression; Transcription; Translation 


\section{Introduction}

Baculoviruses have been isolated from over 300 insect species (David, 1975; Tinsley and Harrap, 1978; Harrap and Payne, 1979). These viruses, especially the Autographa californica multinucleocapsid nuclear polyhedrosis virus (AcMNPV), serve as models for investigations into the molecular basis of insect virus replication and pathogenicity (reviewed in Doerfler and Bohm, 1986). Particular attention has been focused on baculoviruses with lepidopteran hosts, since several of these insects are major pests in agriculture and forestry. One species of particular interest in this regard is the Lymantria dispar multinucleocapsid nuclear polyhedrosis virus (LdMNPV). LdMNPV is currently being utilized as a biopesticide against the gypsy moth, Lymantria dispar (Podgwaite, 1985). A significant advanlage of the virus lies in its extremely narrow host specificity. Since it appears to affect only the gypsy moth, LdMNPV is the control agent of choice in environmentally sensitive areas. LdMNPV's major disadvantages are that it is both less efficacious and more costly to use than chemical pesticides.

For LdMNPV to become a cost effective alternative to chemical pesticides, a means of enhancing its potency must be devised along with a more economical production methodology. The formation of polyhedra (see Vlak and Rohrman (1985) for review) may be an aspect of viral replication conducive to genetic manipulation for potency enhancement. Once the process of virion occlusion into polyhedra is understood, a means of increasing viral potency may be formulated. Mutant baculoviruses, termed few polyhedra (FP) plaque variants, have been isolated which are mostly deficient in the packaging of virions into polyhedra (Ramoska and Hink, 1974; Hink and Strauss, 1976; Fraser and Hink, 1982). Consequently, study of the FP plaque variant is particularly conducive to gaining an understanding into the process of virion occlusion. To that end, we have isolated a LdMNPV FP plaque variant which was used for the characterization of LdMNPV gene expression described in this study. This mutant exhibits the attributes of a FP plaque variant (c.g., production of fcw inclusion bodics that contain very few virions) as exemplified by other baculovirus FP mutants (Slavicek et al., submitted).

Polypeptides that compose LdMNPV capsids and viral proteins expressed in cell culture have been previously described (Padhi et al., 1974; Maskos and Miltenburger, 1981; Singh et al., 1983; Stiles et al., 1983; McClintock et al., 1986), and LdMNPV genomic restriction maps constructed (McClintock and Dougherty, 1988; Smith et al., 1988). We characterized LdMNPV gene expression through the generation of transcription and translation maps. These results extend previous investigations on the structure of the LdMNPV genome and identity of viral proteins. In addition, our study serves as a prerequisite to investigations of specific viral gene products and further characterization of the LdMNPV genome, and to studies on the molecular basis of the FP phenotype of isolate 5-6. 


\section{Materials and Methods}

Cells and virus

The $L$. dispar 652Y ovarian cell line was used in these studies (Goodwin et al., 1978). The cells were propagated in Goodwin's IPL-52B medium with $10 \%$ heat-inactivated fetal bovine serum (HyClone) and $6.25 \mathrm{mM}$ glutamine. The cells were seeded into tissue culture flasks prior to infection with virus. The plaque purified isolate LdMNPV 5-6 was used for infections at 10 or $75 \mathrm{TCID}_{50}$ units per cell.

$R N A$ isolation, gel electrophoresis and Northern hybridization analysis

For transcription mapping studies, $652 \mathrm{Y}$ cells were infected at $10 \mathrm{TCID}_{50}$ units per cell, and harvested at $2,7,16,24,48$, and $72 \mathrm{~h}$ after infection. Cytoplasmic RNA was isolated from viral infected $652 \mathrm{Y}$ cells essentially as described by Friesen and Miller (1985). RNAs were size fractionated on formaldehyde agarose (1.2\%) gels and transferred to nitrocellulose according to standard procedures. Hybridization analysis was carried out essentially as described by Mahmoudi and Lin (1989) using DNA fragments labeled with $\left[\alpha-{ }^{32} \mathrm{P}\right] \mathrm{dCTP}(3000 \mathrm{Ci} / \mathrm{mmol}$, New England Nuclear, Dupont) through nick translation. DNA fragments isolated from LdMNPV cosmid clones (Lanner-Herrera and Slavicek, submitted), covering the genomic regions of $0.7-18.7,18.4-22.3,22.3-32.3,32.3-39.3,39.3-49.9,49.5-61.4$, 61.4-65.7, 65.7-81.2, 81.2-89.8, 89.8-97.1, and 94.8-6.0 map units, were used as probes for the Northern analysis. A LdMNPV polyhedrin gene clone (Ld-7, C. Lanner-Herrera, unpublished) was also used for a probe.

\section{Labeling of proteins in cell culture and protein electrophoresis}

$1 \times 10^{6} 652 \mathrm{Y}$ cells were seeded into T-25 flasks (Corning) and infected at 75 TCID $_{50}$ units per cell with LdMNPV isolate 5-6. One $h$ prior to label addition, the culture medium was removed and replaced with Goodwin's modified IL-P medium lacking methionine and fetal calf serum. At 4, 8, 12, 16, 20, 24, 28, 32, 36, 40, 44, $46,48,50,52,54,58,62,66,70,80,90$, and $100 \mathrm{~h}$ post infection (p.i.) the culture medium was removed and replaced with $1 \mathrm{ml}$ of Goodwin's modified IL-P medium lacking methionine and fetal calf serum, and containing $40 \mu \mathrm{Ci}\left[{ }^{35} \mathrm{~S}\right]$ methionine (1245 Ci/mmol, New England Nuclear, Dupont). After a $1 \mathrm{~h}$ labeling period the cells were harvested, spun down, resuspended in Goodwin's medium, repelleted, and suspended in phosphate-buffered saline. One volume of cracking buffer ( $2 \%$ SDS, 4\% 2-mercaptoethanol, $10 \%$ glycerol, $50 \mathrm{mM}$ Tris, $\mathrm{pH} 6.8$ ) was added, the samples were boiled for 10 minutes, and subjected to SDS polyacrylamide gel electrophoresis (SDS PAGE) on 12\% gels using the discontinuous system of 
Laemmli (1970). After electrophoresis, the gels were treated with an autoradiographic enhancer (Enhance, New England Nuclear), dried, and the labeled proteins were visualized by autoradiography.

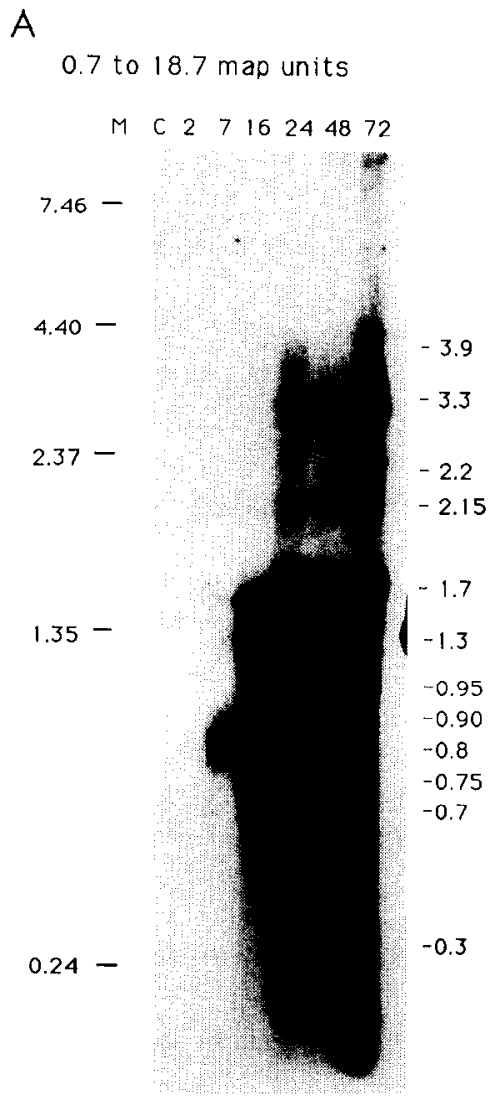

Fig. 1. (A) Northern hybridization analysis of cytoplasmic RNAs from $652 \mathrm{Y}$ cells infected with LdMNPV isolate 5-6. RNA was isolated from infected cells at $2,7,16,24,48$, and $72 \mathrm{~h}$ p.i., separated on formaldehyde-agarose gels, transferred to nitrocellulose, hybridized with radioactive DNA probes, and the hybrids visualized by autoradiography. The region of the genome covered by the DNA probes, and the times of RNA isolation after viral infection and from uninfected cells (C), are indicated above the autoradiogram. The size (in $\mathrm{kb}$ ) of RNA markers (M) is indicated on the left of the blot, and the approximate size of viral transcripts is shown on the right. (B) Schematic diagram of the Northern hybridization results. The genomic regions covered by the DNA probes used in the hybridization analysis are represented by the lines above the linear depiction of the viral genome. The times of RNA isolation after viral infection are indicated on the left of the diagram. The identified RNAs are indicated above the DNA probes, and their size is shown in $\mathrm{kb}$. The relative hybridization intensity is indicated by the number of pluses by each transcript, with one plus indicating weak, two moderate, and three strong. 
B

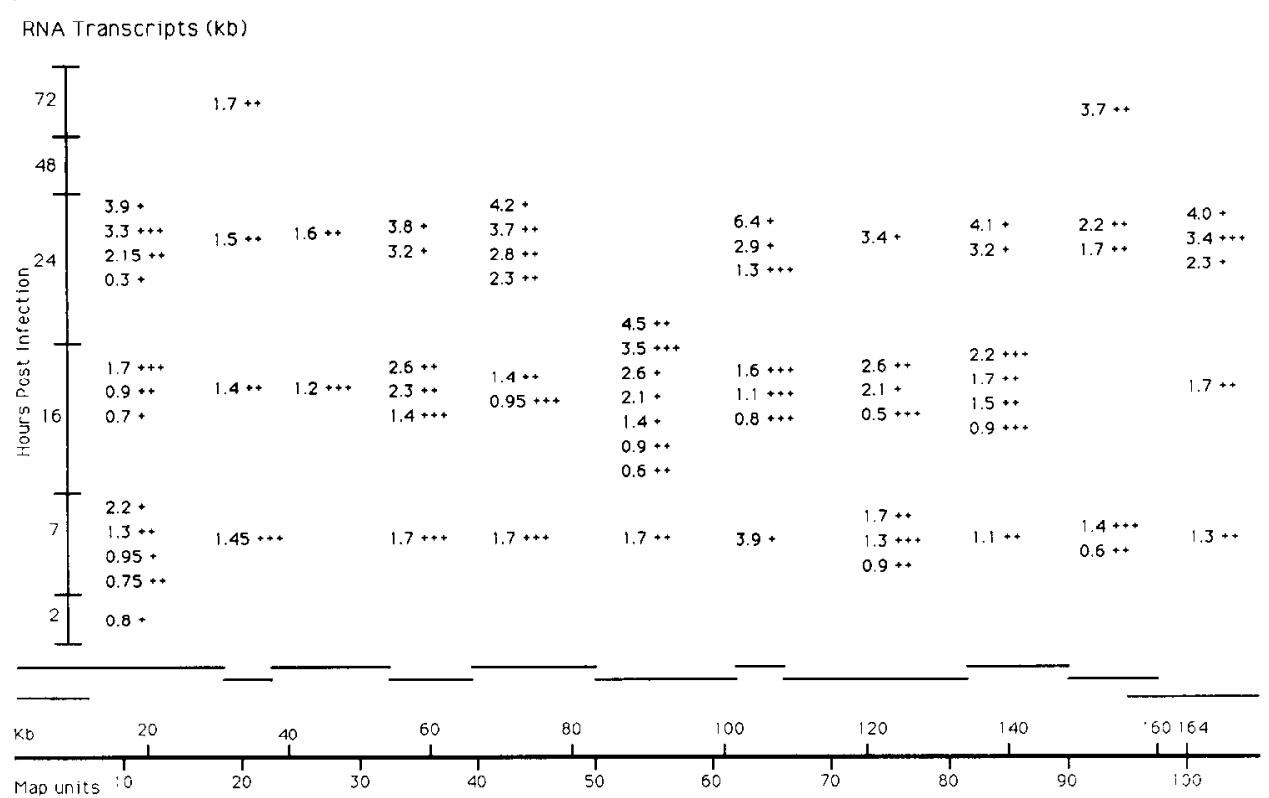

Fig. 1 (continued).

Hybrid selection of viral RNA, in vitro protein synthesis and SDS PAGE

Cytoplasmic RNA was isolated as described above from $652 \mathrm{Y}$ cells infected with LdMNPV clonal isolate 5-6 at 10 TCID $_{50}$ units per cell at 16,24 , and $48 \mathrm{~h}$ after infection. DNA was attached to nitrocellulose filters as described by Kafatos et al. (1979), and hybrid selections were performed essentially as described by McGrogan et al. (1979) and Vlak et al. (1981). The overlapping cosmid clones used for hybrid selection covered the genomic regions from 0.7-22.4, 17.3-40.0, 31.7-55.6, 49.5-76.8, 62.7-83.5, and 80.9-6.0 map units. RNA was translated in a cell free micrococcal nuclease-treated rabbit reticulocyte lysate (Promega) according to the manufacturer's directions. The translation reaction contained $50 \mu \mathrm{Ci}\left[{ }^{35} \mathrm{~S}\right]$ methionine $(1169 \mathrm{Ci} / \mathrm{mmol})$ and $10 \mu \mathrm{l}$ of eluted RNA in a total volume of $50 \mu \mathrm{l}$. Cracking buffer ( 1.5 vols.) was added to 1 vol. of translation reaction, the samples were boiled, loaded on $12 \%$ SDS polyacrylamide gels, and subjected to electrophoresis. The gels were fixed and prepared for autoradiography as described above.

\section{Results}

\section{Spatial and temporal mapping of LdMNPV transcripts}

Cytoplasmic RNA was isolated from infected cells $2,7,16,24,48$, and $72 \mathrm{~h}$ p.i., fractionated on agarose formaldehyde gels, transferred to nitrocellulose, and 
probed with labeled restriction endonuclease fragments from cosmid clones of the LdMNPV genome. The DNA fragments for this analysis covered the genomic regions from $0.7-18.7,18.4-22.3,22.3-32.3,32.3-39.3,39.3-49.9,49.5-61.4,61.4-$ $65.7,65.7-81.2,81.2-89.8,89.8-97.1$, and $94.8-6.0$ map units. Representative results of this analysis are shown in Fig. 1A, and are described below. The probe covering the genomic region from 0.7 to 18.7 map units identified 12 transcripts. Five transcripts were detected by $7 \mathrm{~h}$ p.i. $(0.75,0.8,0.95,1.3$, and $2.2 \mathrm{~kb})$, and the $0.8 \mathrm{~kb}$ RNA was observed at $2 \mathrm{~h}$ p.i. after a longer exposure time. Of the early RNAs, the $2.2 \mathrm{~kb}$ transcript was observed only at $7 \mathrm{~h}$ p.i., whereas the remaining were expressed through $72 \mathrm{~h}$ p.i. The hybridization signal was strongest with the $1.3,1.7$, and $3.3 \mathrm{~kb}$ RNAs from 24 to $72 \mathrm{~h}$ p.i. The polyhedrin gene lies within this genomic region (data not shown). When a LdMNPV polyhedrin specific probe was used in Northern analysis, three prominent transcripts of $1.4,1.6$, and $3.3 \mathrm{~kb}$ were identified (Fig. 1A), which probably correspond to the 1.3, 1.7, and $3.3 \mathrm{~kb}$ RNAs identified with the probe covering the region from 0.7 to 18.7 map units. Densitometric analysis of the autoradiogram indicates that the sum of relative amounts of the 1.4 and $1.6 \mathrm{~kb}$ RNAs are approximately equal to the amount of the $3.3 \mathrm{~kb}$ RNA at $48 \mathrm{~h}$ p.i. (data not shown). The remaining transcripts, 0.7 and $0.9 \mathrm{~kb}$, and $0.3,2.15$, and $3.9 \mathrm{~kb}$ were first detected at 16 and $24 \mathrm{~h}$ p.i., respectively.

A summary of Northern analysis results are diagrammed in Fig. 1B. The relative hybridization signal (weak, moderate, or strong) is indicated by the number of asterisks (Fig. 2). Generally, a viral transcript detected at 16 or 24 h p.i. persisted throughout the time course of the study $(72 \mathrm{~h}$ p.i.). Sixty-five distinct transcripts were identified and mapped to the LdMNPV genome (Fig. 1B). One very early transcript was identified at $2 \mathrm{~h} \mathrm{p}$.i., and 15 early messages were detected at $7 \mathrm{~h} \mathrm{p}$.i. Most viral transcripts were expressed late in infection, first being detected from 16 to $24 \mathrm{~h}$ p.i. The genes coding for these messages were found to be distributed thoughout the viral genome.

The disruption of a single gene has been shown to be sufficient to generate the FP phcnotypc within AcMNPV (Beames and Summers, 1989). Consequently, it is likely that the expression of a gene(s) within isolate 5-6 has been disrupted, and will not have been identified in this characterization of LdMPNV expression. Since the nature of this type of andlysis is nol exhaustive, it is probable that other LdMNPV transcripts and proteins were also not identified.

\section{Identification of viral specific proteins}

The expression of viral proteins in infected $652 \mathrm{Y}$ cells was monitored through $\left[{ }^{35}\right.$ S]methionine pulse labeling over a period from 4 to $100 \mathrm{~h}$ p.i. The cells were infected at $75 \mathrm{TCID}_{50}$ units per cell. By $24 \mathrm{~h}$ p.i. the cells uniformly exhibited drawn out processes and swollen nuclei, attributes of infected cells, suggesting a synchronous infection. Shown in Fig. 2 is the analysis of the period from 4 to $44 \mathrm{~h}$ p.i. At later times p.i., $46-100 \mathrm{~h}$, no new viral proteins were detected (data not shown). As the course of infection progressed, the synthesis of cellular proteins 


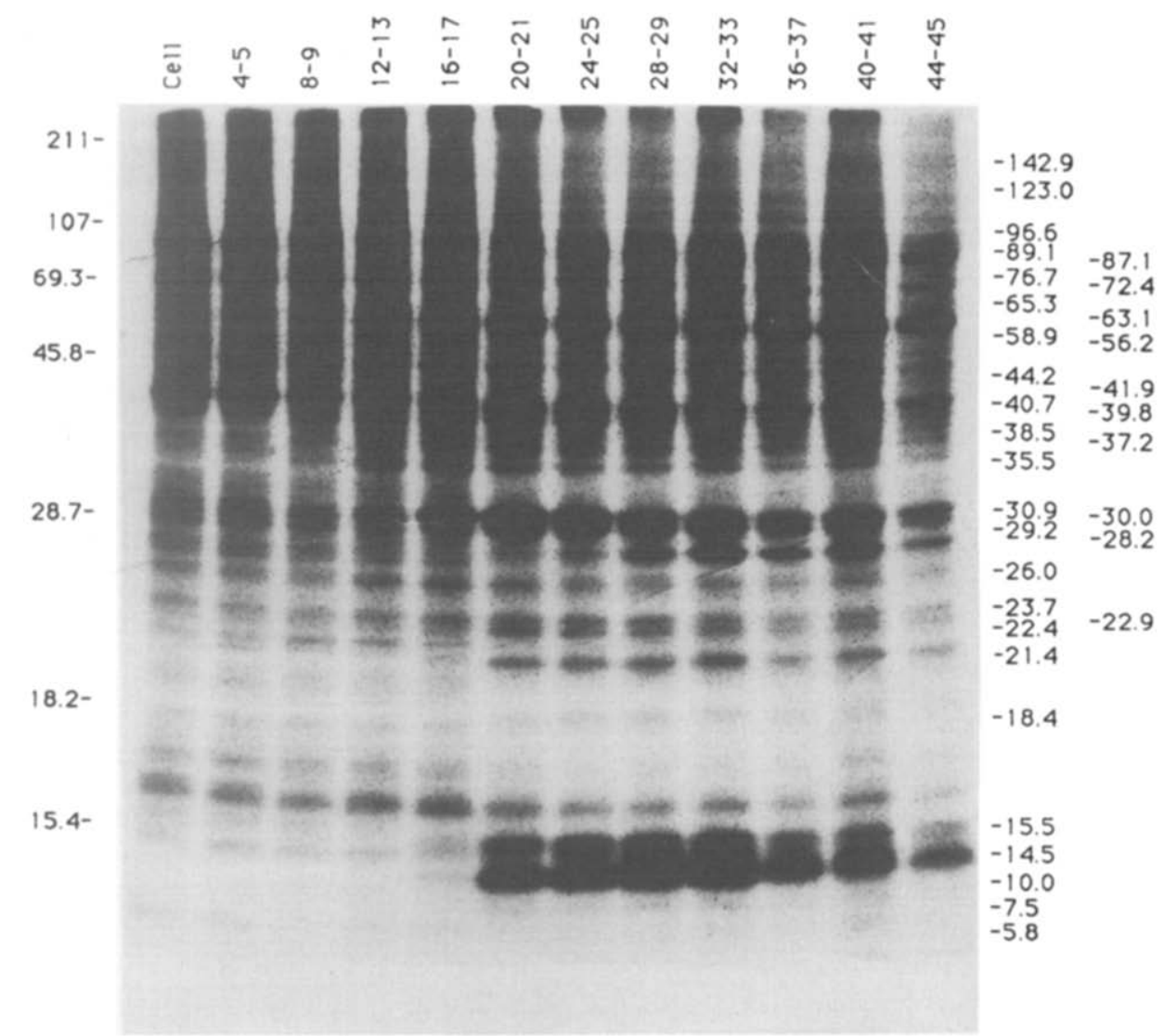

Fig. 2. Analysis of $\left[{ }^{35} \mathrm{~S}\right]$ methionine labelled intracellular proteins. $652 \mathrm{Y}$ cells were infected with LdMNPV at $75 \mathrm{TCID}_{50}$ units per cell. After washing the cells with methionine-free medium as indicated in the Materials and Methods section, label was added at various times after infection as indicated by the first number (in $\mathrm{h}$ ) above each lane. After a $1 \mathrm{~h}$ pulse period, the cells were harvested, proteins prepared and separated by SDS-PAGE, and the labeled proteins were visualized by autoradiography. The proteins in the lane marked Cell are from uninfected cells pulsed for $1 \mathrm{~h}$ with label. The numbers on the left indicate the molecular weight $\left(\times 10^{3}\right)$ of protein markers, and those on the right the apparent molecular weights of proteins specific to LdMNPV infected cells.

decreased until virtually only viral proteins were detected. The recovery of labeled acid insoluble material decreased significantly over the course of the study; the $\mathrm{dpm}$ recovered at $100 \mathrm{~h}$ p.i. was over one order of magnitude less that at $24 \mathrm{~h}$ p.i.

Similar to viral protein expression in other baculoviruses (Carstens et al., 1979; Wood, 1980; Maruniak and Summers, 1981), LdMNPV protein expression was found to occur in a sequential fashion. During the early phase of viral replication (4-12 h p.i.), four proteins were identified (Fig. 3). A protein with an apparent molecular weight of $44.2 \mathrm{kDa}$ was present at $4 \mathrm{~h}$ p.i., and absent by the next time point at $8 \mathrm{~h}$ p.i. The other proteins were first identified at $8 \mathrm{~h}$ p.i., and last detected at $12 \mathrm{~h}$ p.i. (41.9 and $22.4 \mathrm{kDa})$ or $16 \mathrm{~h}$ p.i. $(29.2 \mathrm{kDa})$. 


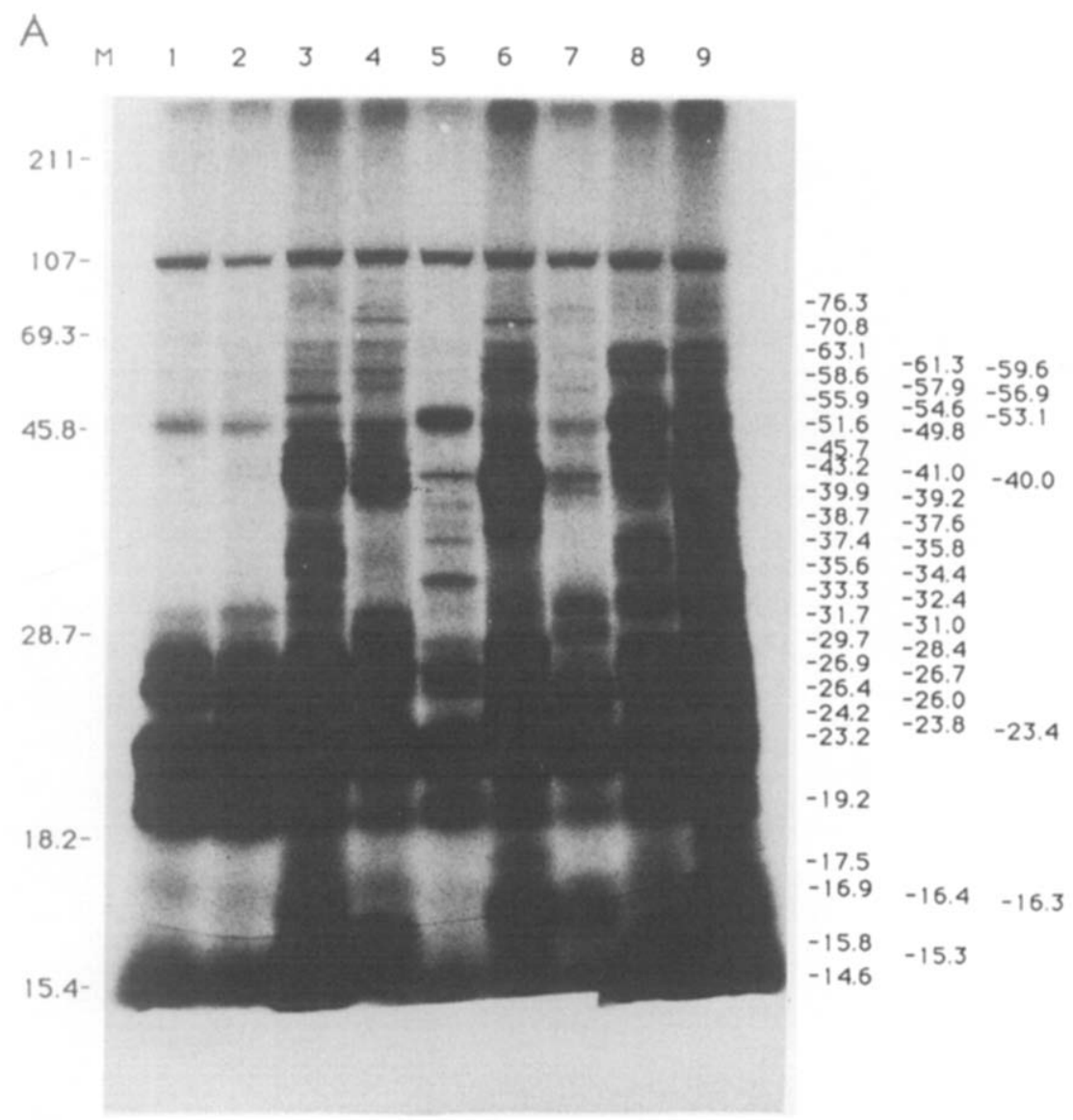

Fig. 3. In vitro translation products of hybrid selected RNAs. Overlapping DNA fragments covering the entire LdMNPV genome were used to hybrid select RNA isolated from $652 \mathrm{Y}$ cells infected with LdMNPV at 16,24 , and $48 \mathrm{~h}$ p.i. The RNAs were added to a reticulocyte lysate in vitro translation system containing $\left[{ }^{35} \mathrm{~S}\right]$ methionine. The translation products were resolved by SDS-PAGE and visualized by autoradiography. (A) The in vitro translation products from RNA isolated $24 \mathrm{~h}$ p.i. The DNA fragments covering the genomic regions from $0.7-22.4,17.3-40.0,31.7-55.6,49.5-76.8,62.7-83.5$, and 80.9-6.0 map units were used for hybrid selection, and coded for the proteins shown in lanes 3-8, respectively. Lane 1 contains the products after addition of only $\left[{ }^{35} S\right]$ methionine, lane 2 the proteins from mock infected cells after hybrid selection with LdMNPV genomic DNA, and lane 9 contains proteins generated using RNAs hybrid selected with LdMNPV genomic DNA. On the left of the autoradiogram are shown the position and molecular weights $\left(\times 10^{3}\right)$ of protein markers (lane $M$ ), and on the right are indicated the apparent molecular weights of expressed proteins. (B) A schematic representation of the in vitro translation results using RNAs isolated 16, 24, and $48 \mathrm{~h}$ p.i. The genomic regions covered by the DNA fragments used for hybrid selection are indicated by the lines above the linear depiction of the viral genome. The time of RNA isolation after viral infection is indicated on the left of the diagram. The expressed proteins, depicted by apparent molecular weight $\left(\times 10^{3}\right)$, are shown above the DNA fragment used for hybrid selection, and within the respective time after infection. 

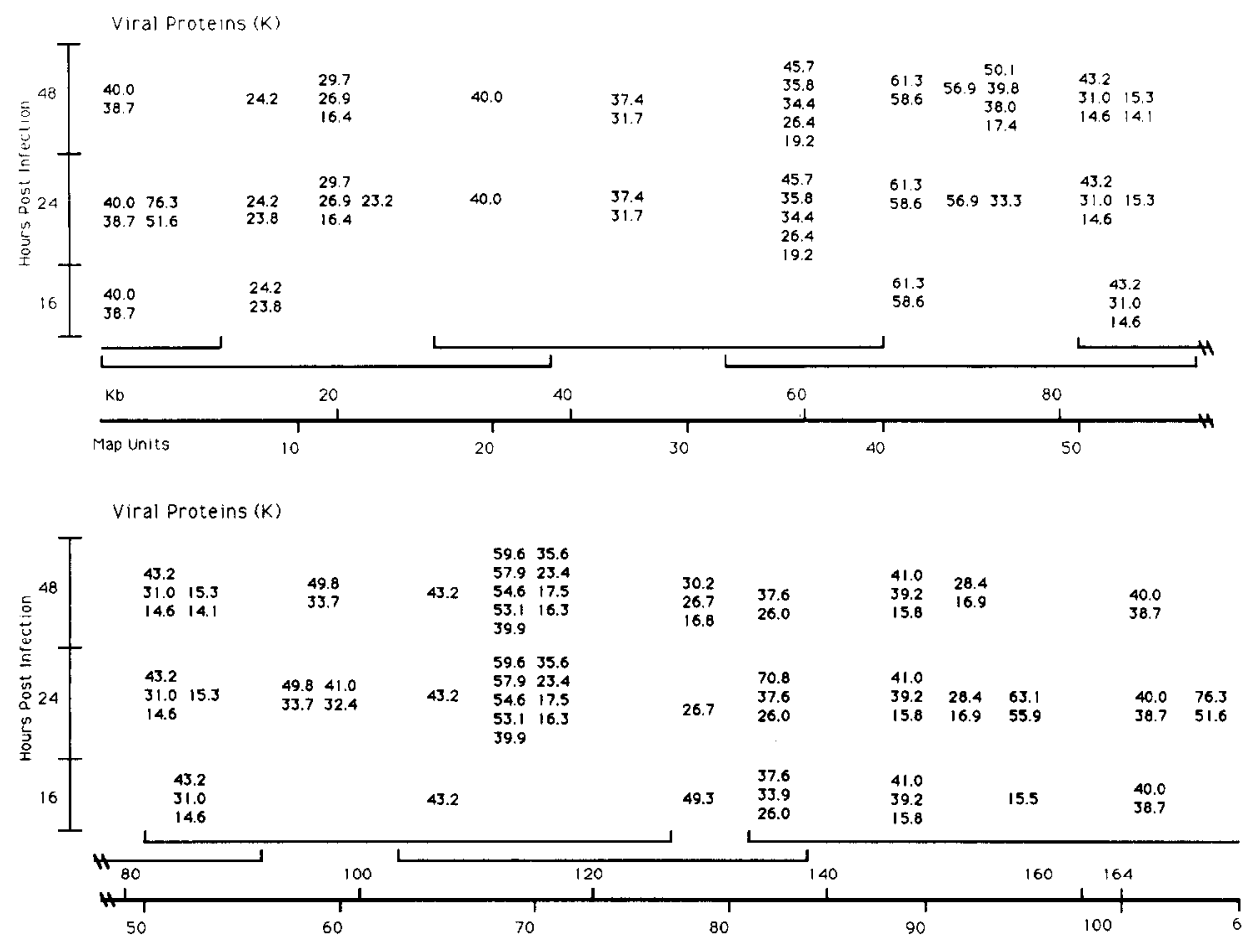

Fig. 3 (continued).

Twenty-four additional viral polypeptides were detected during the intermediate phase (12-24 h p.i.) of viral replication. These proteins had apparent molecular weights of $123,96.6,89.1,87.1,76.7,72.4,58.9,56.2,40.7,39.8,38.5,37.2,35.5$, $30.9,30.0,26.0,23.7,22.9,21.4,15.5,14.5,10.0,7.5$, and $5.8 \mathrm{kDa}$. The $30.9 \mathrm{kDa}$ protein, first detected at $16 \mathrm{~h}$ p.i., was one of the more prominent proteins detected. This protein is similar to the polyhedrin, in size and expression pattern, described in LdMNPV (Maskos and Miltenburger, 1981; Singh et al., 1983), and possibly corresponds to the LdMNPV $30.5 \mathrm{kDa}$ protein suggested to be polyhedrin by McClintock et al., (1986). The other most prominent proteins identified were the $14.5,40.7,56.2$, and $58.9 \mathrm{kDa}$ proteins.

During the late phase of viral expression ( $>24 \mathrm{~h}$ p.i.), five proteins of 142.9, $65.3,63.1,28.2$, and $18.4 \mathrm{kDa}$ were identified. A total of 33 viral polypeptides were identified in this analysis.

\section{Spatial mapping of in vitro LdMNPV translation products}

Cytoplasmic RNA was isolated from LdMNPV infected 652Y cells 16, 24, and $48 \mathrm{~h}$ p.i. for hybrid selection and in vitro translation analysis. The autoradiogram of the $\left[{ }^{35} \mathrm{~S}\right]$ methionine labelled proteins generated from RNAs isolated $24 \mathrm{~h}$ p.i. is 
shown in Fig. 3A, and the results of this analysis are diagrammed in Fig. 3B. The partially overlapping DNA fragments used for hybrid selection covered the genomic regions $0.7-22.4,17.3-40.0,31.7-55.6,49.5-76.8,62.7-83.5$, and 80.9-6.0 map units. The regions of fragment overlap allowed the confirmation of viral protein identification and mapping with two distinct DNA fragments. Viral proteins of the same apparent molecular weight identified with two overlapping DNA fragments were assigned to the region of probe overlap, and those that were distinct were assigned to the non-overlapping region on the schematic translation map (Fig. 3B). For example, nine distinct viral proteins were obtained with RNA selected with a DNA fragment that contains the genomic region from 0.7 to 22.4 map units. Four of these proteins, 38.7, 40.0, 51.6, and $76.3 \mathrm{kDa}$, had the same apparent molecular weights as four viral proteins identified with a DNA fragment covering the region from 80.9 to 6.0 map units. The location of these polypeptides was assigned to the region from 0.7 to 6.0 map units. Another protein, of $40.0 \mathrm{kDa}$, had the same molecular weight as a protein identified with the DNA fragment containing the region from 17.3 to 40.0 map units, and was assigned the location from 31.7 to 40.0 map units. The $40.0 \mathrm{kDa}$ protein was obtained with DNA fragments covering three genomic regions, 80.9-6.0, 0.7-22.4, and 17.3-40.0 map units. As such, the origin of this protein could not be unequivocally assigned within the region from 0.7 to 22.4 map units. The $40.0 \mathrm{kDa}$ protein was therefore placed in both regions of DNA fragment overlap, 0.7-6.0 and 31.7 to 40.0 map units, to reflect this ambiguity. The remaining proteins identified with the DNA fragment from 0.7 to 22.4 map units exhibited molecular weights of $16.4,23.2,24.2,26.9$, $29.7,56.9$, and $61.3 \mathrm{kDa}$, and were assigned to the region of the genome unique to this DNA fragment $(6.0 \simeq 17.3$ map units, Fig. 3B).

The genomic locations of viral proteins identified with the other DNA fragments covering the genome are depicted in Fig. 3B. A few of the proteins were detected at only one of the three times p.i. investigated. For example, a $15.5 \mathrm{kDa}$ protein was detected only at $16 \mathrm{~h}$ p.i. (83.5-0.7 map units), 51.6 and $76.3 \mathrm{kDa}$ proteins were specific to $24 \mathrm{~h}$ p.i. (0.7-6.0 map units), and the 18.8 and $30.2 \mathrm{kDa}$ proteins were specific to $48 \mathrm{~h}$ p.i. (76.8-80.9 map units). In contrast, other proteins were present at 16,24 , and $48 \mathrm{~h}$ p.i. (e.g., 58.6 and $61.3 \mathrm{kDa}, 31.7-40.0$ map units), some at 16 and $24 \mathrm{~h}$ p.i. (e.g., $23.8 \mathrm{kDa}, 6.0-17.3$ map units), and others at 24 and 48 h p.i. (e.g., 33.7 and $49.8 \mathrm{kDa}, 55.6-62.7$ map units).

Sixty-one distinct viral polypeptides were identified and their genomic origins mapped. Sixteen of these proteins were detected $16 \mathrm{~h}$ p.i., 36 at $24 \mathrm{~h}$ p.i., and 7 at $48 \mathrm{~h}$ p.i. Most of these proteins ( 41 in total) were detected at the 16,24 , and $48 \mathrm{~h}$ time points or at 24 and $48 \mathrm{~h}$ p.i. The proteins expressed late in infection were found to have genomic origins dispersed throughout the viral genome.

The in vitro translation reactions contained the same amount of label, and were charged with RNA selected by using comparable amounts of the DNA fragments. The resulting intensity of the autoradiogram signal is, therefore, an indicator of the relative abundance of viral messages, and/or the methionine content of the proteins. The autoradiographic signals from the $14.6 \mathrm{kDa}$ (49.5-55.6 map units), $15.5 \mathrm{kDa}$ (83.5-0.7 map units), and the $16.3,23.4$, and $39.9 \mathrm{kDa}$ (62.7-76.8 map 
units) proteins were significantly greater than those detected from the other proteins (Fig. 4). The 15.5 and $16.3 \mathrm{kDa}$ proteins were most prominent at $16 \mathrm{~h}$ p.i., the $23.4 \mathrm{kDa}$ protein at $24 \mathrm{~h}$ p.i., the $14.6 \mathrm{kDa}$ equally at 24 and $48 \mathrm{~h}$ p.i., and the $39.9 \mathrm{kDa}$ protein at 16,24 , and $48 \mathrm{~h}$ p.i. These proteins therefore appear to be major LdMNPV proteins expressed during viral replication.

\section{Discussion}

Characterization of LdMNPV gene expression through transcription and translation mapping is necessary for an understanding of viral genome organization and gene expression. Previous work on LdMNPV has focused on genome cloning and restriction enzyme mapping (Smith et al., 1988; McClintock and Dougherty, 1988), characterization of the polyhedrin gene (Smith et al., 1988), and identification of viral proteins (Padhi et al., 1974; Maskos and Miltenburger, 1981; Singh et al., 1983; Stiles et al., 1983; McClintock et al., 1986). The results of the present analysis provide a spatial and temporal characterization of LdMNPV gene expression, thus extending the knowledge of genome organization within the baculoviridae.

Through transcriptional analysis, 65 viral transcripts were identified and their approximate genomic locations mapped (Fig. 1B). Most viral RNAs were present by $24 \mathrm{~h}$ p.i., with two first appearing at $72 \mathrm{~h}$ p.i. Once a transcript was initially detected, it appeared to be expressed throughout the time course of the analysis. However, detection of the termination of transcription of a specific RNA would likely have been obscured due to the number of RNAs identified with the DNA probes used. Temporal transcription analysis of a LdMNPV putative immediate early gene has shown that some viral messages are expressed only at early times p.i. (data not shown). Expression of LdMNPV transcripts occurs in a temporal fashion with the first RNA detected at $2 \mathrm{~h}$ p.i., and the latest transcript at $72 \mathrm{~h} \mathrm{p.i.}$ Most RNAs, 47 in total, were first detected from 16 to $24 \mathrm{~h}$ p.i.

Transcriptional analysis of AcMNPV has identified at least 50 transcripts (Rohel and Faulkner, 1984), suggesting a similar level of genomic complexity compared to LdMNPV. The greater number of LdMNPV transcripts identified compared to studies of AcMNPV may be a consequence of genomic size. The LdMNPV isolate used in this analysis has a genome of $164 \mathrm{~kb}$ in length, compared to approximately $133 \mathrm{~kb}$ for the genomes of most AcMNPV isolates. In addition, the temporal pattern of LdMNPV transcriptional expression is similar to that of AcMNPV (Rohel and Faulkner, 1984; Mainprize et al., 1986/87).

The genes coding for LdMNPV transcripts are stochastically distributed throughout the genome with the exception of the region from 22.3 to 32.3 map units. Only two transcripts of 1.2 and $1.6 \mathrm{~kb}$ in length were mapped to this genomic region, encompassing $16.5 \mathrm{~kb}$, suggesting that this region is largely transcriptionally silent. When expressed as a ratio of total transcript length to coding region size, this region exhibited a ratio of $0.17 \mathrm{~kb}$ RNA : $1.0 \mathrm{~kb}$ DNA, compared to a ratio of 
approximately $1.0 \mathrm{~kb}$ RNA: $1.0 \mathrm{~kb}$ DNA for the rest of the DNA probes used in this analysis.

Thirty-three viral proteins expressed in cell culture were identified through labeling with $\left[{ }^{35} S\right]$ methionine. Expression of viral polypeptides appears to be under temporal regulation, as has been found in other baculoviruses (Doerfler and Bohm, 1986, for review). The number and size of LdMNPV proteins identified in this study are in good agreement with the study by McClintock et al. (1986), in which 28 viral proteins were identified. The additional proteins identified in this analysis may be a consequence of the genomic size of the isolate used. Isolate 5-6 has a genome of approximately $164 \mathrm{~kb}$, whereas $5-7 \mathrm{D}$, the isolate used by McClintock et al. (1986), is about $133 \mathrm{~kb}$ in length. While several few polyhedra plaque variants identified in AcMNPV are a consequence of DNA insertions, the larger genomic size of isolate 5-6 compared to the 5-7D isolate is probably not solely a consequence of a possible DNA insertion. Other LdMNPV isolates under study in our lab also have genomic sizes of approximately $164 \mathrm{~kb}$. Moreover, the isolate characterized by Smith et al. (1988) has a genome length of $166.6 \mathrm{~kb}$.

Translation analysis identified and mapped the approximate genomic origin of 61 viral proteins. It is likely that not all of these proteins are derived from different viral genes, but that some are a consequence of a post-translational modification (e.g., phosphorylation, Richter et al., 1988) that gives rise to an altered electrophoretic mobility. Transcription of the messages for these viral polypeptides appears to be under temporal regulation as evidenced by the in vitro protein expression pattern. Some viral proteins were expressed at specific times p.i., and others throughout the analysis time course (Fig. 3B). The genes coding for messages expressed late in infection were mapped to fragments throughout the genome. The genomic distribution of these LdMNPV genes is similar to the organization of these genes in AcMNPV (Rohel and Faulkner, 1984).

Analysis of viral proteins expressed in cell culture and by in vitro translation analysis identified many proteins of similar molecular weight between approximately $14 \mathrm{kDa}$ and $76 \mathrm{kDa}$. For cxamplc, viral proteins of $76.7,39.8$, and $15.5 \mathrm{kDa}$ expressed in cell culture are close in size to the $76.3,39.8$ and $15.3 \mathrm{kDa}$ viral proteins expressed in vitro (Figs. 2 and 3). More high molecular weight proteins were identified in the analysis of viral proteins expressed in cell culture (e.g. 123 and $96.6 \mathrm{kDa}$ ) than when viral messages were expressed in vitro, possibly as a consequence of the degradation of large mRNAs. However, many more viral proteins were identified after expression in vitro. A number of viral proteins have similar molecular weights (e.g., a $33.3 \mathrm{kDa}$ and a $33.7 \mathrm{kDa}$ protein were mapped to the regions from 40.0 to 49.5 and 55.6 to 62.7 map units, respectively), and therefore could not be distinguished in the analysis of viral proteins expressed in cell culture.

When the transcription and translation maps are compared, similarities and differences exist between the numbers of transcripts and proteins mapped to a specific region. For example, 14 transcripts and 14 proteins were mapped to the regions from 61.4 to 81.2 and 62.7 to 80.9 map units, respectively. In another region, 6 RNAs and 5 proteins were localized to the regions from 32.3 to 39.9 and 
31.7 to 40 map units, respectively. In contrast, 4 transcripts and only 1 protein were mapped to the regions from 18.4 to 22.3 and 17.3 to 22.4 map units, respectively. There was a good correlation between transcript and protein number in a region of the genome that appears largely transcriptionally silent. Two transcripts and two proteins were mapped to this region (from 22.3 to 32.3 and 22.4 to 31.7 map units, respectively).

This analysis will facilitate further studies on the organization of the LdMNPV genome and specific gene products. Additionally, these studies serve as a prerequisite for an investigation into the molecular basis of the few polyhedra phenotype of isolatc 5-6.

\section{Acknowledgment}

The expert technical assistance of Nancy Hayes-Plazolles is gratefully acknowledged.

\section{References}

Beames, B. and Summers, M.D. (1989) Location and nucleotide sequence of the $25 \mathrm{~K}$ protein missing from baculovirus few polyhedra (FP) mutants. Virology 168, 344-353.

Carstens, E.B., Tjia, S.T. and Doerfler, W. (1979) Infection of Spodoptera frugiperda cells with Autographa californica nuclear polyhedrosis virus. Virology 99, 386-398.

David, W.A.L. (1975) The status of viruses pathogenic for insects and mites. Annu. Rev. Entomol. 20, 97-117.

Doerfler, W. and Bohm, P. (1986) The molecular biology of baculoviruses. Curr. Top. Microbiol. Immunol. 131, 1-168.

Fraser, M.J. and Hink, W.F. (1982) The isolation and characterization of the MP and FP plaque variants of Galleria mellonella nuclear polyhedrosis virus. Virology 117, 366-378.

Friesen, P.D. and Miller, L.K. (1985) Temporal regulation of baculovirus RNA: overlapping early and late transcripts. J. Virol. 54, 392-400.

Goodwin, R.H., Tompkins, G.J. and McCawley, P. (1978) Gypsy moth cell lines divergent in viral susceptibility. In Vitro 14, 485-494.

Harrap, K.A. and Payne, C.C. (1979) The structural properties and identification of insect viruses. Adv. Virus Res. 25, 273-355.

Hink, W.F. and Strauss, E. (1976) Replication and passage of alfalfa looper nuclear polyhedrosis virus plaque variants in cloned cell cultures and larval stages of four host species. J. Invertebr. Pathol. 27, $49-55$.

Kafatos, F.C., Jones, C.W. and Etstratiadis, A. (1979) Determination of nucleic acid sequence homologies and relative concentrations by a dot hybridization procedure. Nucleic Acids Res. 7, $1541-1553$

Laemmli, U.K. (1970) Cleavage of structural proteins during the assembly of the head of bacteriophage T4. Nature $227,680-685$.

Mahmoudi, M. and Lin, V.K. (1989) Comparison of two different hybridization systems in Northern transfer analysis. Biotechniques 7, 331-333.

Mainprize, T.H., Lee, K. and Miller, L.K. (1986/87) Variation in the temporal expression of overlapping baculovirus transcripts. Virus Res. 6, 85-99.

Maruniak, J.E. and Summers, M.D. (1981) Autographa californica nuclear polyhedrosis virus phosphoproteins and synthesis of intracellular proteins after virus infection. Virology 109, 25-34.

Maskos, C.B. and Miltenburger, H.G. (1981) SDS-PAGE comparative studies on the polyhedral and 
viral polypeptides of the nuclear polyhedrosis viruses of Mamestra brassicae, Autographa californica, and Lymantria dispar. J. Invertebr. Pathol. 37, 174-180.

McClintock, J.T. and Dougherty, E.M. (1988) Restriction mapping of Lymantria dispar nuclear polyhedrosis virus DNA: localization of the polyhedrin gene and identification of four homologous regions. J. Gen. Virol. 69, 2303-2312.

McClintock, J.T., Dougherty, E.M. and Weiner, R.M. (1986) Protein synthesis in gypsy moth cells infected with a nuclear polyhedrosis virus of Lymantria dispar. Virus Res. 5, 307-322.

McGrogan, M., Spector, D.J., Goldenberg C.J., Halbert, D. and Raskas, H.J. (1979) Purification of specific adenovirus 2 RNAs by preparative hybridization and selective thermal elution. Nucleic Acids Res. 6, 593-607.

Padhi, S.B., Eikenberry, E.F. and Chase, T.jr. (1974) Electrophoresis of the proteins of the nuclear polyhedrosis virus of Purthetria dispar. Intervirology 4, 333-345.

Podgwaite, J.D. (1985) Strategies for field use of baculoviruses. In: K. Maramorosch and K.E. Sherman (Eds.), Viral Insecticides for Biological Control. pp. 775-797. Academic Press, Orlando, FL.

Ramoska, W.A. and Hink, W.F. (1974) Electron microscope examination of two plaque variants from a nuclear polyhedrosis virus of the alfalfa looper, Autographa californica. J. Invertebr. Pathol. 23, 197-201.

Richter, J.D., Slavicek, J.M., Schneider, J.F. and Jones, N.C. (1988) Heterogeneity of adenovirus type 5 E1A proteins: multiple serine phosphorylations induce slow-migrating electrophoretic variants but do not affect E1A-induced transcriptional activation or transformation. J. Virol. 62, 1948-1955.

Rohel, D.Z. and Faulkner, P. (1984) Time course analysis and mapping of Autographa californica nuclear polyhedrosis virus transcripts. J. Virol. 50, 739-747.

Singh, S.P., Gudauskas, R.T. and Harper, J.D. (1983) High resolution two-dimensional gel electrophoresis of structural proteins of baculoviruses of Autographa californica and Porthetria (Lymantria) dispar. Virology 125, 370-380.

Smith, I.R.L., Van Beek, N.A.M., Podgwaite, J.D. and Wood, H.A. (1988) Physical map and polyhedrin gene sequence of Lymantria dispar nuclear polyhedrosis virus. Gene 71, 97-105.

Stiles, B., Burand, J.P., Meda, M. and Wood, H.A. (1983) Characterization of gypsy moth (Lymantria dispar) nuclear polyhedrosis virus. Appl. Environ. Microbiol. 46, 297-303.

Tinsley, T.W. and Harrap, K.A. (1978) Viruses of invertebrates. Compr. Virol. 12, 1-101.

Vlak, J.M. and Rohrmann, G.F. (1985) The nature of polyhedrin. In: K. Maramorosch and K.E. Sherman (Eds.), Viral Insecticides for Biological Control. pp. 489-542. Academic Press, Orlando, FL.

Vlak, J.M., Smith, G.E. and Summers, M.D. (1981) Hybridization selection and in vitro translation of Autographa californica nuclear polyhedrosis virus mRNA. J. Virol. 40, 762-771.

Wood, H.A. (1980) Autographa californica nuclear polyhedrosis virus-induced proteins in tissue culture. Virology 102, 21-27. 